\title{
Taking Teams Seriously in the Co-Creation of Firms and Economic Agency
}

Hull Kristensen, Peer; Lotz, Maja

Document Version

Final published version

Publication date:

2010

License

CC BY-NC-ND

Citation for published version (APA):

Hull Kristensen, P., \& Lotz, M. (2010). Taking Teams Seriously in the Co-Creation of Firms and Economic Agency. Department of Business and Politics. Copenhagen Business School.

Link to publication in CBS Research Portal

\section{General rights}

Copyright and moral rights for the publications made accessible in the public portal are retained by the authors and/or other copyright owners and it is a condition of accessing publications that users recognise and abide by the legal requirements associated with these rights.

\section{Take down policy}

If you believe that this document breaches copyright please contact us (research.lib@cbs.dk) providing details, and we will remove access to the work immediately and investigate your claim. 
Copenhagen Business School

HANDELSHØJSKOLEN

Taking Teams Seriously in the Co-Creation of Firms AND ECONOMIC AGENCY

By Peer Hull Kristensen and Maja Lotz 


\title{
Taking Teams Seriously in the Co-CReation of Firms
}

\section{AND ECONOMIC AGENCY}

(c) By Peer Hull Kristensen and Maja Lotz

Working paper no 72, 2010

\author{
International Center for Business and Politics \\ Copenhagen Business School \\ Steen Blichers Vej 22 \\ DK-2000 Frederiksberg \\ Phone: +4538153585 \\ E-mail: $\underline{\text { cbp@cbp.cbs }}$ \\ www.cbs.dk/cbp
}

ISBN

87-91690-75-7 


\begin{abstract}
This paper suggests that it is time to take the agency of teams seriously. Whereas the debate has previously focused on how firms may function more effectively by using team-based work-organization, our aim is to discuss and understand how teams effect the evolutionary dynamic of companies. Fieldwork in four Danish manufacturing companies helped us discover that firms as "communities of teams" are highly dynamic entities with complex layers of different team forms that operate, innovate and improve by constantly recombining work, collaborating across organizational divisions and redistributing authority, thereby challenging some of the existing "idioms" of team research and theories of the firm. The paper builds on these findings as we attempt to rethink research on teams by re-describing the evolutionary dynamics of firms and suggesting some themes that call for comparative research.
\end{abstract}

Keywords: Work-organization, team communities, economic agency, theory of the firm 


\section{Introduction}

In 1987 Richard Whitley (1987) published an article, “Taking Firms seriously as Economic Actors”, which turned out to become programmatic for studies of how firms are socially constructed in different ways in different societies, i.e. the literature on national business systems (NBS) (Whitley and Kristensen, 1996; 1997; Whitley, 1999 and Morgan et al. 2005). Departing from Coase, Williamsson and Chandler's explanations of large firms generally, Whitley insisted that firms should be given a more open-minded and yet systematic consideration:

Taking firms seriously as economic actors implies that their boundaries, constitution and development become significant foci of analysis and that the conditions under which particular kinds of firms become established, interact and change require systematic consideration. Rather than reducing them to epiphenomena of market processes or class conflicts, firms needs to be conceptualized as interdependent, semi-autonomous economic agents, which are able to control and direct the uses of resources by virtue of delegated property rights in ways which make a difference to economic and social outcomes (Whitley, 1987, p 126).

Since then studies of the nature of firms have accumulated new knowledge about how differently they are constructed in different national contexts. For instance, in some societies firms are part of business groups which structure their behavior according to the typical Chandlerian corporation, as the individual firm takes part in a political-economic coalition that limits its autonomy and independence but increases its resource base, while in other countries they are regulated to be more strictly atomistic economic actors.

While firms were studied in their social and institutional context, the global landscape changed. In some countries like the U.S. clusters of innovative firms came to challenge the dominance of large, multidivisional companies. Outsourcing and globalization changed the patterns of production logistics. The internally focused R\&D labs broke up, and “open innovation” (Chesbrough, 2003) taking place in global networks offered a new challenge in understanding firms. Within companies, work-organization started to integrate planning and execution so that firms could change and redefine their roles continuously, in an attempt to achieve both cost reductions and speedy innovation (Herrigel, 2007). This in turn has led to firms constituted as an ecology of work- and project-teams. As a result, the former self-evident conceptualization of firms as fundamentally constituted as hierarchies - though built on a diversity of different institutional building blocks in different countries - is being questioned (Stark 2009, Heckcher and Adler 2007).

Therefore it is time to pose Whitley's question concerning “work teams", if we hypothetically expect that teams may be the building blocks of current economic organizations. Following Whitley, teams should then be studied as interdependent, semi-autonomous economic agents partly able to control and direct the uses of resources, rather than epiphenomena of managerial decision processes and hierarchical control ex ante.

Surely, work teams are in most cases the outcomes of top managerial initiatives and as such expressions of the behavior of firms as economic agents (Barker 1993; Sewell 1998). But creating teams as a novel way of 
organizing work may have a certain twist regarding where agency is placed in the organization in different situations; that is, who can legitimately initiate particular actions.

Penrose (1959) is widely seen to have captured the basic logic of how firms grow and develop. According to her, managers are continuously developing novel routines to expand the rational operations of firms. When routines become mature they can be left to subordinates and workers to be carried out in repetitive ways. The core competence of the firm then is to hierarchically create novel routines embraced with a certain, distinct logic. This evolutionary logic of the firm is foundational in, for example, Nelson and Winter (1982).

The NBS approach complicated the hierarchy by showing how differences in financial systems and vocational training systems helped shape both the social position of workers and managers, thereby, for example, providing highly divergent forms of authority among countries. But NBS basically took for granted that the hierarchical division among workers and managers followed the Penrosian pattern.

One important aspect of team-organization is to delegate not only a well defined set of operational activities and routines to work teams, but also to make them responsible for the continuous improvements of products, services and routines and, to varying degrees, for co-creation of innovative change (Sundstrom et al. 1990; Mueller 1994; Den Hertog and Tolner 1996; Uhl-Bien and Graen 1998; Benders \& Van Hootegem 1999; Bacharach 2005; Benders 2006). Thus they seem to break with the received wisdom on the hierarchically structured evolutionary dynamics of firms.

Yet, a vast amount of the literature on team-organization neglects the serious reconsideration of the evolutionary dynamics of firms from the vantage point of teams gradually gaining roles that used to constitute the monopoly of managers. The literature generally takes for granted that responsibilities are delegated to teams top-down (and may be taken back by the higher echelons of the firm) (e.g. Kanter 1979; Womack, Jones and Roos 1990; Senge 1990; Kuipers and Witte 2005; Caroll et al. 2006; Strang and Jung 2009). Mostly this view is embedded in the design of studies, which tend to focus on relations between a team and the managerial level.

Such a framing of the object tends to ignore important questions. What happens to the managerial function when a multiplicity of teams constantly doubt and change existing routines? What happens to managerial authority when teams become the primary location for improvements of performance? What happens to political coalition making when continuous improvements differ among teams and locations are changed over time? What happens when teams, by taking seriously their obligations for continuous improvements and innovations, collide in struggles over demarcations? And what happens when rival teams decide that the best way of developing their community is to lay off members who the majority think have the wrong attitude? Do teams in such instances not start defining the problems that managers have to solve rather than vice versa? Therefore, it is important to actually study how teams and their members are mutually constituted and 
jointly co-create the firm as a 'community of team communities' and whether this changes the growth and evolutionary logic of a firm.

Such an approach entails a focus on how relational configurations of teams (Elias 1978; Emirbayer 1997; Tilly 2006) become constituted, demarcated and developed through the interactions and everyday encounters of people within concrete organizational and institutional contexts. It seeks to understand how teams shape the actual work organizing practices as well as how they are shaped by them. Overall, teams must be understood as emergent collaborative communities (Hecksher and Adler 2007) which "materialize" in cooperative endeavors towards a common task-situation, during which they reveal their intra- and interrelational processes among members of a team vis-a-vis other teams. Thus teams are not treated as "given" entities in isolation, but as forming a processual structure that becomes constituted and gains meaning, boundaries and development in relation to other team communities (Elias 1974; Lotz 2009; Brown and Duguid 2001; Beckhy 2003). Further, Kozlowski and Ilgen (2006) observe that teams and communities of teams evolve through a lineage of emergent states where their effectiveness as economic agents changes as they learn to resolve problems of (self-) regulation and governance. Departing from this view, it is our aim to explore 1) how team communities at the level of everyday work organizing practices become shaped and governed through complex interaction and 2) how these micro dynamics of teams shape new organizational forms and the evolutionary patterns of firms.

\subsection{The Structure of the Paper}

The next section positions our approach within the general theoretical debate on teams and further specifies the possible consequences of changing to team-based organizational forms. The four case-companies are then introduced, followed by a section in which we describe our experiences and reflections on observations made on team-based organizations in these Danish manufacturing firms. While trying to take the empirical manifestations, relational and evolutionary dynamics of teamwork seriously, our study reflects an iterative research journey through a confusing empirical landscape. The fourth section takes stock of our findings compared to existing "rules-of-thumb" in the team literature, while also moving the focus from the individual team to that of team communities in order to capture the dynamic embedded in a firm. In the final section tentative outlines of this dynamic are proposed, showing how it may be rooted in different institutional legacies and contexts, and calling for a set of comparative studies.

\section{Studying Teams as Co-Creative Economic Actors}

Interest in team-based work organization and its benefits exploded in the academic and managerial literature of the 1990s as well as among practitioners (Kirkman and Rosen 1999; Delbridge et al 2000). The concept and the benefits of teamwork are ambiguous and widely debated in empirical research, indicating that there are as many varieties and effects of teamwork as there are organizations experimenting with it (Casey 1995; Guzzo and Dickson 1996; Den Hertog and Tolner 1996; Knights and McCabe 2000; Koch 2004).

Nevertheless, the current debate on teams draws on a set of traditions which have resulted in a number of distinctive types and design of teams (Mueller et al 2000, Van den Broek et al. 2004). In particular, a wide range of bipolar team models can be found in the literature. Examples are: 'Swedish' and 'Japanese' models (Berggren: 1993 in Benders and Van Hootegem 1999), involvement and productivity teams (Mueller 1994), 
high- and low road teams (Bacon \& Blyton: 2000), strong and weak teams (Koch and Buhl 2001) and neoTaylorist and anti-Taylorist teams (Pruijt 2002). Although these models classify teams in various ways, all reflect different aspects of two prominent types: socio-technical and lean teams, inspired by the sociotechnical school (Sewell 1998; Benders and Van Hootegem 1999) and the lean production philosophy rooted in Japan (Womack 1990; Kenney and Florida 1993). There now follows a closer look at these two team models in order to better address the implications of analyzing the empirical manifestations and relational dynamics of team processes via such dichotomies.

Scholars (e.g. Mueller 1994; Sewell 1998; Benders and Van Hootegem 1999; Delbridge et al 2000; Stein 2001; Townsend 2007) stress that the socio-technical team model is typically initiated as a means of enhancing the autonomy of workers and the quality of working life, whereas the rationale embedded in lean teams is to increase workers' efficiency and performance. The socio-technical team model, by striving for autonomy, codetermination and job enrichment through continuous skill development and reintegration of conception and execution, is opposed to a Taylorist discipline and division of work (Van Hootegem et al 2005). Team autonomy is not a key feature of the lean team model (although it may embody a degree of participation).The lean team model also makes use of multi-skilled workers and continuous skill development. It allocates tasks to work units (U-cell) and strong work unit leaders accompanied by quality control circles and continuous improvement systems (Kaizen) to increase efficiency and productivity (Macduffie 1995; Benders 2000). The two positions represent two highly different movements that have tried to appeal to their opponents (Pruijt 2002), thereby blurring the two team concepts, to the effect that the ideology of teams becomes hegemonic because all groupings can interpret the phenomena as in their best interests (Sinclair 1992). Thus the bipolar way of theorizing teams has become problematic, not only because demarcation lines are unclear, but also because the empirical manifestations of current team work practices question bipolar team models (Minssen 2006; Wergin 2003; Scarbrough and Kinnie 2003).

The dual typology of teams is counterproductive as it focuses analytical effort on classifying diverse practices, and therefore easily tends to oversimplify the debate to the neglect of what is going on in 'reality' and how it is evolving. The dichotomies may also imply a rigid separateness when in practice elements often overlap significantly and constitute a variety of hybrids (Benders \& Van Hootegem 1999; Bacon and Blyton 2000). Consequently, bipolar team models make it difficult to study how a gradual mix of "old" and "new" team practices, reflecting complex and contradictory arrangements, may characterize changes in today's organizational landscape. Another implication is that bipolar team models are typically framed within a hierarchical conception of team structure and performance. As a result it becomes difficult to acknowledge how dual team models may in fact represent various modes of autonomy and control, which are not mutually exclusive and which may not only be constituted in hierarchical ways. For instance, a "rule-of-thumb" in the team literature is that socio-technical teams are characterized by a relatively high autonomy which is positively correlated to high performance, while lean teams are characterized by a relatively low autonomy which is similarly associated with high performance (Steijn 2001). Framed in this way, it becomes problematic to take into account how the nature and degree of autonomy varies and continuously changes over time depending on the concrete team structure, work situation and organizational context (Stewart and Barrick 2000). A dichotomist perspective is neither able to deal with the paradox that both too little and too much autonomy appear counter-productive thus calling for experiments with new governance practices and performance measures within and across teams. Nor does it acknowledge how aspects of autonomy and 
interdependence not only concern the team as an entity, but are intrinsically shaped by both intra- and interrelational team processes.

Accordingly, more recent research on teams has moved beyond dichotomist team models by introducing much more differentiated typologies of teams and nuanced understandings of the structures of autonomy and interdependence in teams and their effectiveness (for an elaborated review see Kozlowski and Ilgen 2006). Yet surprisingly few studies explore the managerial challenges and governance principles of teams moving beyond a hierarchical conception of the organization (e.g. Sewell 1998). Likewise, there is a tendency to keep treating teams as rather static organizational forms or entities (e.g. Keller 2001; Kuipers and de Witte 2005) instead of studying them as co-creative processes constituted and continuously developed by both endogenous and exogenous relations (for a good exception see for instance Vallas 2003; Garibaldo and Rebecchi 2004). In contrast, our focal point in this paper is the intra- and inter-relational dynamics of team communities. Studying these micro patterns of interdependencies, we wish to contribute to a more finegrained understanding of how the everyday interactions and co-creations among team members in and across teams call for new experimental governance practices that may constitute the firm in novel ways. Put differently, from a relational approach, we aim to develop our understanding of how team communities may be supported and monitored by non-hierarchical processes, and how they evolve over time and may become constitutive for the firm and its evolutionary dynamics.

A team-oriented change in the organization of the firm may have important consequences for how, who and through which processes the boundaries, constitution and development of both teams and firms become determined. At least in a transitory phase, traditional concepts of governance encounter a number of novel challenges. If teams are still hierarchically controlled and decisions still reside with top managers, a lot of tension may be created because with the change, managers have lost the feel for the experimental process of developing from past experience future routines for the teams and the firm. Alternatively, the future evolution of the firm could be decided by internal market mechanisms that hand over power to define future routines to the teams having shown the highest relative performance in the past. This would, however, soon lead the firm astray as emerging needs and novel, preliminary and volatile teams would be deselected to the effect that exploitation would take dominance at the expense of exploration and innovation. Thus, for firms that aim at enhancing their cost-effectiveness to finance more innovation (Herrigel, 2007), neither market nor hierarchy seem to constitute good governance solutions.

Consequently, we argue that the more teams become the focal agency of a complex organization, the more difficult it is to imagine that the firm can escape from having its dynamic constituted by complex negotiation and deliberation processes among teams, involving both political and economic aspects and a strong sense of responsibility for the future among all the constitutive team elements of the firm. The question is whether the company derives its identity and changing roles from the mutual negotiation process among its constitutive teams or from the entrepreneurial ideas of its principals. Will agency then have been relocated from the firm as such to rest with the community of teams? And will the ability of the firm as economic agency be dependent on the ongoing negotiations among its teams? What then becomes the nature of the firm? These are the questions guiding this paper. 


\section{Methods AND CASES}

Empirically, the paper draws on four longitudinal case studies conducted from 2002-2008. The first two phases were carried out as an extensive exploration aimed at attaining a general view as to how Danish firms experiment with team-based forms of organizing. The third phase was an intensive exploration based on indepth case studies focused on achieving a more nuanced view of how new organizational patterns and modes of governance unfold within and between various communities of teams (Yin, 2003; Stake, 1998).

The four case study organizations operate in the engineering, medical instruments and distillery industries in Denmark; the sites studied are all part of an MNC and had around 12 years of experience with team-based organizational forms. The cases were selected from a larger sample of 12 companies which were visited in 2002 (1-2 days of interviews in each company). This study was followed up by second visits in 2005-2006 when one day was spent on each site. In the third phase, 2007-2008, four companies were investigated 'mini'-ethnographically, with 8-12 days spent on each site. The four case companies were selected for investigation because, as will be seen later, we wrongly thought that they exemplified four different types of team-organization (i.e. extreme cases) (Flyvbjerg 2001). Tracing the relational dynamics of team communities at the level of everyday work organizing practices requires a focus on the work experiences and lives of organizational members, i.e. an understanding of what people actually do, how they collaborate, how they connect (and disconnect), how they manage and coordinate their daily work practices in order to accomplish their work etc. To achieve this, the studies were triangulated between three different data sources: talk, observation and documents (Kunda 2006). The methods deployed included formal and informal interviewing of organization members at all levels (employees and managers), observations and secondary data (Fetterman, 1989; Spradley, 1979; VanMaanen, 1988). In total 120 interviews plus various observation and informal conversations were carried out. Finally, we went back and presented our findings in a seminar for each of the four firms to give them feedback and the opportunity to correct possible mistakes.

Due to the exploratory nature of this research, we do not claim the results of our study to be representative. Instead of generalization, the aim is to generate more fine-grained insights and questions on how team communities (and communities of teams) may evolve as emergent configurations and how they may become constitutive for the firm and its evolutionary dynamics. In what follows, we provide a short introduction to the four in-depth case studies (pseudonyms are used).

Tools Ltd. now positions itself as a problem solver and supplier of total tooling solutions, including customized tools and know-how intensive services. It supplies "traditional” products such as cutting tools, lamina inserts, tool fixtures, fastening systems, and measuring equipment from a wide range of suppliers, but in combination with, for example, services such as tool maintenance, calibration and production optimization. Through close interaction with customers, for which Tools Ltd. makes continuous improvement in tools management, it has developed a wide range of competencies, and what it learns from one customer can be used to service others, thus making production optimization into a process of cocreation. The company has advanced from servicing a few traditional branches to a broad and increasingly 
advanced set of sectors. It has expanded internationally since 1995 to become a small Danish multinational with subsidiaries and sales offices abroad. It employs 650 people, 450 of whom are working in Denmark (our study took place at its headquarters where most of these 450 employees work). It is fully owned by management and employees (of whom $85 \%$ own shares). Team work takes place in the unconventional physical facilities of 'roofed villages' with no walls separating production, stores, sales, administration and R\&D.

Hydraulic Ltd. produces hydraulic, electro-hydraulic and electric solutions for slow vehicles (e.g tractors). Its expertise is in control and steering, work and propelling functions, high-performance components and integrated systems for a wide range of applications. With approximately 9,000 employees worldwide and revenue of more than $\$ 1.7$ billion it has sales, manufacturing, and engineering capabilities on all major continents. The MNC was constituted through a merger between Danish and German firms that took over an American one, which had been the headquarters until the Danes regained control. During these changes in corporate ownership and governance, the Danish facility was making radical innovations in valve technology and introducing team organization on the factory floor. In this way it achieved a high position as a system contractor for a number of U.S OEMs. Employment in the Danish facilities, which we studied, grew from 700 employees in 2000 to 2,400 in 2008.

The Danish site of Spirit Ltd. which we studied is located in Fünen, and employs 250 people in bottling, storing and distributing different types of spirits and wines. During the last decades the company has been sold four times. During our visits it belonged to a Swedish state-owned multinational. Changing ownership and tough market competition have forced the factory into continuous improvement in quality and into cost reduction. Rivalry and negotiations over setting, and meeting benchmarks among the different plants in Finland, Sweden and Denmark have been used to contest and evaluate the comparative advantages of each factory. For two years, uncertainty prevailed about which of the factories should be closed and during this period the team-organization operated under fierce pressure. Hardly had the Danish facility won this contest when a new French owner took over in 2008 and reframed rivalry over mandates.

Health Ltd. is one of the world's leading providers of medical analyzers. The company employs nearly 1700 people worldwide and their products are sold in more than 100 countries. Its headquarters (our study-site with 800 employees) are in Denmark and its global organization comprises three product companies and a number of international sales companies responsible for sales and distribution of products and services. Until recently, Health Ltd was a Danish family-owned company which was going multinational by developing products and services through close ties to hospitals all over the world. However, in 2003 Health Ltd. was taken over by a large American multinational that wanted to change the original high discretion teamorganization towards a lean model, along with a more intensive and constant pressure for innovative changes. While medical analyzers and production of instruments consitute the core métier, the company also offers a wide range of, for example, liquids, samplers and services such as process analysis, IT systems, quality and technical support and training. Its strategy is to assist acute sections of hospitals to make continuous improvements. 


\section{Exploring Empirically the Micro Dynamics of Team Communities in Danish Manufacturing}

Given our longitudinal studies, the cases are rich in information on how the reorganization of Danish firms towards team-based work forms takes place as an un-linear process without given outcomes. Rather, the reorganization in these companies reflects ongoing processes of recombining "new" and "old" work practices, roles and rules in experimental ways at all organizational levels. And it is exactly the multilevel experimental character of such processes that cast doubt on the relevance of both a Penrosian perspective of the firm and rules-of-thumb in much team literature. In what follows we take a closer look at our empirical observations and examine how analytical reflections changed the way in which we conceived of observations.

\section{Visit 1}

Compared to a study from the early 1980s (Kristensen 1986) Danish managers had by 2002 discovered the comparative advantages of leaving increasing responsibilities to Danish factory-floors. Whereas in the 1980s autonomy and teams were part of a fight between hourly paid and salaried staff, showing many similarities with the shaky introduction of teamwork later in the U.S. (Vallas 2003), field visits in 2002 (Kristensen 2003) made it clear that team-based high performance work organizations (HPWOs) were evolving rapidly, constituting a general core element in strategic partnerships between managers and shop stewards in many Danish plants. But the visits to several plant sites also revealed that the single concept of teams may refer to very different realities (see also Minssen 2006). In some, teams were u-formed cells, in others they looked like a department and in yet others they were ad hoc groups working on temporary projects. Moreover, they transcended from one to another over time. They were also constituted very differently; for example, some were created hierarchically by managers who appointed team leaders, while in others the team leader role would rotate among the members; some teams constituted themselves by electing a team leader and others even saw the community of team leaders as an extension of the union club, which would nominate the people who could be chosen as leader. Our sample even included a firm owned by a large Danish corporation where a large group of elected shop stewards managed the entire floor. Discourses across firms ignored this heterodox reality, meaning that people would talk about "apples", while listeners would hear "pears".

\section{Visit 2}

Our next phase of extensive case-visits therefore aimed at identifying a set of "ideal types" of team-based HPWOs and we believed we had identified four different types in the four selected case-companies mentioned above.

Spirits Ltd. constituted a lower boundary case in which teams had been formed and team leaders selected jointly by management and union representatives, forming a partnership of enthusiasts, but struggling with a majority of lukewarm opponents who would rather gossip negatively in the corridors than engage in serious discussion about possibilities for improvements. This partnership was particularly interested in our investigation to learn about additional organizing principles by studying other firms. Much of our further 
inquiry into other firms thus concerned finding solutions to this problem (discussed in the literature as "team climate” (Kozlowski and Ilgen 2006).

For example, we found that teams where the team-leader role rotated among members were less prone to split into fiery souls and lukewarm opponents. Here, team members would be more constructive as they prepared themselves for the coming team leader role. This minor detail seemingly improved the ability of team members to take on the roles of others and to improve on their shifting roles in the team. Yet in most cases where rotation had been tried, it had failed because many did not want to be leaders.

In Hydraulic Ltd. a constitutive principle seemed able to solve this problem. Hydraulic had introduced a Total Production Management(TPM) concept, in which all team members had operational duties and managerial responsibilities for carrying out continuous improvements in, for example, organizing (team leader), maintenance, logistics, quality, safety and environment. In addition to being a member of the operational team, each employee was part of a secondary cross-team joining colleagues with similar managerial tasks from different operative teams. In this system, operational teams were competing over performance, yet they were also learning from each other about possible improvements. Thus all team members were located in a nexus, receiving inspiration and ideas for continuous improvements and innovations, making it easier for everyone to actively contribute, making team members more equal. Furthermore, the team leader role was continuously being elaborated by a sophisticated joint educational program organized by the further training institutions in the region and the plant's HR department. Hydraulic Ltd. was thus expected to constitute the upper boundary case placing other cases between Spirits Ltd and Hydraulic Ltd.

Health Ltd. seemed to be a mixture. Here, all workers were members of quite permanent operational teams with a hierarchically appointed team leader, and most workers would simultaneously have a second job in another team. Often, workers would also join ad hoc teams working on development projects. Thus an operational team would embody a group of people who knew what was going on in most parts of the factory, and who could compare themselves with the rest, receive suggestions for improvements and be able to coordinate itself with other teams through personal ties. Workers were very attentive to the propensity of team leaders to sub-optimize, and they would ask for interventions of a very active group of shop stewards to create more formal coordination across teams when needed. Shop stewards, often jointly with upper managers, used the Works Council to form ad hoc committees, representing the operational teams, on novel issues for coordinated action.

Finally, Tools Ltd. provided a highly interdependent and laterally accountable form of team organization. First, all employees were part a different primary operational team. In addition, they would continuously and in abundance form ad hoc teams, for example to serve a new customer, engage in an R\&D project, or to set up a foreign subsidiary. The variability of ad hoc teams was high: they were typically led by the little group of seven people from the R\&Dteam, and most operational teams were involved in a number of ad hoc projects. Continually recombining teams through ad hoc teams created a flow of challenges and ideas for improvements for the operational teams, which seemed to run close to top performance despite there being 
no monitoring system measuring teams and individuals. Because there was no measurement of individuals, teams or departments, ad hoc teams could be formed easily and did not have to first overcome suboptimal concerns of fiefdoms. As already shown by Dalton (1959), traditional hierarchies had difficulties in maintaining functional unity, because department leaders would find opportunistic ways of undermining and taking advantage of these systems, creating an environment in which all tried to look after narrow departmental self-interests. The literature on teams is ripe with similar observations (see e.g. Vallas 2003) that teams define themselves against the others to gain advantages by playing opportunistically against the rest, turning thereby a potential community of teams into a set of hostile fiefdoms. Tools Ltd. had a monitoring system, but it worked very differently than is normal for lean organizations. As more than $85 \%$ of employees owned shares, they were highly interested in the overall performance of the company. Reports on the year up to the previous day would be published every morning. Outcomes which were higher than budgeted would lead to monthly bonuses of absolute equal size for all employees. Budgeted performances, on the other hand, were made to pay such high dividends to shareholders that they would cover interest rates paid on banking loans raised to buy the shares. Thus the individual would always be able to see the overall performance of the firm in relation to their personal economic situation.

All field sites but Tools Ltd. imagined possibilities for improving their HPWOs, so we expected that they would make it possible to investigate four diverse types of evolutionary logics and thereby construct a new typology.

\section{Visit 3}

By our return 6 months later everything had changed. In both Hydraulic Ltd. and Health Ltd., pressure from American HQ to change over to lean systems had overruled the past working practices. In Hydraulic Ltd. this even resulted in a change from a Danish manager to an American one, causing the breakup of a tight partnership between union representatives and top managers, and effecting a collapse in the TPM system that had created an admirable collaboration across teams. The factory had instead fragmented into mutually hostile fiefdoms. Hydraulic Ltd. was simultaneously increasing capacity to meet the exploding growth in demand for its products, considering what to subcontract and introducing lean principles. In Health Ltd. changes had created such a mess that union representatives were mainly concerned with finding a way of preserving managers belonging to past partnerships, to enable the joint search for a compromise between the former and the new organization. In both companies workers and shop stewards were struggling to compensate for ongoing mismanagement and trying to prevent the processes of restructuring from ruining the firm's reputation among customers. Spirits Ltd. had in the meantime changed for the better. The owner had proclaimed that subsidiaries would be benchmarked in preparation for a set of plant closures. This had changed the game and everybody was struggling enthusiastically to perform. By introducing a second job, as in Health Ltd., and by engaging most people in changing or building new production lines, everybody had become enthusiasts for making improvements. Thus all three sites were in chaos, and yet the participants showed no signs of despair. But we had lost our aspiration for a set of "ideal types".

The sites demonstrated a surprising changeability, which a fourth visit confirmed. Once more the situation had changed. Hydraulic Ltd. had got rid of American managers and a new managerial team was eagerly 
repairing the damage in order to form a new partnership with shop stewards to find ways of reconfiguring the HPWO. Health Ltd. had lost the managers of former partnerships, but had instead got a Polish manager, who was eager to learn how to combine lean with Danish high discretion. Spirit Ltd. had won the benchmark battle and was integrating a former Swedish plant into its activities, introducing whole new lines and making surprisingly quick improvements to prepare themselves for a new owner. Most of the practices from the first visits were still in place and had been recombined in novel ways with new organizational elements, but hardly anyone held a comprehensive view of the current HPWO. Only in Tools Ltd. were the constitutive principles still in place, apparently because they allowed the firm to absorb continuous changes and redefinitions of roles within the existing organization.

What runs through our empirical field observations is that the firms are able to readjust in autonomous ways despite highly volatile ownership, changing managerial teams, templates and customer relations by constantly refiguring their organization. A Penrosian systematic accumulation of new routines is not flowing from managers and team governance changes frequently.

\section{Three Recurrent Observations of Team Work Practices Derived from our Field Studies}

To understand this empirical landscape through existing bipolar team models seemed of little help. Our aspiration to construct a typology of different team-based organizational logics also had to be given up. Instead, what did emerge from the observations was a "hotchpotch" landscape of diverse and constantly changing team organizing practices, both among and within teams.

However, although the ongoing reconfigurations of teams unfolded in diverse ways, the most dynamic and co-creative practices typically encompassed a highly flexible three-layered team structure consisting of operational or primary teams (e.g. a production team, sales team etc), secondary cross-teams for identifying and distributing managerial improvements among the teams, and tertiary or ad hoc teams composed according to a broad range of development tasks by involving members from many primary teams. The combination of these three ways of relating gave rise to various collaborative and rival relationships, paving the way for different and often changing organizational architecture of team communities. The organization of work within primary teams structured employee work practices because of their collaboration and rivalry with other teams, while cross-teams and ad hoc teams generated a collaborative, competitive and recombinatory process by bringing together practices and knowledge across the firm. Along with this general organizing principle, our fieldwork identified three recurrent observations (author a).

Firstly, all four cases had developed an ability to constantly reorganize and recombine their work organizing practices within and across units and teams. Thus, despite different organizational architectures, all showed a common ability to capture, compensate for and yet try to get the best out of new organizational designs, templates for governance etc imposed from headquarters or by top managers. For example, both Health Ltd. and Hydraulic Ltd. expected to learn a lot by experimenting with some lean elements but, contrary to their American principals, they had no expectations of achieving a final system. For 25 years one holistic 
organizational system after another had set new directions, but this process could in retrospect be seen as a long experimental search for useful new building blocks to be integrated with existing practices. For instance, a team worker describes the "merger" between the company's former work practices and new lean principles in this way: "We take from lean what we can use...that is, we make it work within the specific unit. We're good at finding creative solutions when necessary" (Isaac, Health Ltd.). After these changes others would follow and new lessons would be learned (see Benders and Van Bijisterveld 2000; Steijn 2001 for similar observations).

The second recurrent observation was that each of the firms had managed to build up a significant ability to collaborate and co-create across traditional organizational boundaries, be they internal (employees/managers, among teams) or external (customers, partners, suppliers, vocational and labor market institutions).

Consequently, organization members at all levels were engaged in ongoing distributed search practices reflecting a significant ability to change roles and routines through the daily interactive work activities (see also Sabel 2006). We observed operators collaborating with construction to develop new products and processes, searching for better technical solutions together with machine suppliers, or finding novel ways of solving problems for customers. The story of Bruce illustrates how this takes place in practice:

An empirical glimpse of everyday reorganizations and the co-creation of collaborative co-designing teams

Bruce is an EXPERT when it comes to Tools Ltd's most hardcore technically refined measuring machine. He has worked at the company for about six years and describes himself as a bit of a nerd and a workaholic. For example, he says: "Working with the measuring equipment makes me all electric. I'm really passionate about it ... it's my hobby as well as my work. I just can't stop ... That's why I'm so good at what I do."

Bruce started off in the grinding department. After two years he wanted to learn something new and asked his boss whether he might work with the measuring machine. Since then he has trained himself and some of his colleagues in measuring techniques. Just now Bruce is instructing two co-workers. He mentors them one afternoon a week. They receive training and test the programs and settings they have learnt under Bruce's formalized 18-month program of supervision.

Now Bruce has grown tired of just instructing others without receiving any input himself. So last week he submitted a proposal to the team leader and the production manager ... to break down a wall between two different measuring rooms. This will enable him to get acquainted with a new measuring machine, whilst continuing to train his colleagues on the other machine. The proposal was 
presented, discussed and decided on within a day. He says, "it’s cool to feel that people are listening to you".

Bruce continues about his work: "I've had many opportunities to constantly learn new stuff, to widen my horizons and try out new things." He describes how he works with the German company, the producer of the measuring machine, sharing experiences and exchanging views to build up a joint pool of know-how on the programming of the machine and its potential. He has also translated the instructions from German into Danish and from Danish into English and has adapted the manual. He has agreed with Walther to carry out other similar jobs. According to Bruce, these tasks take most of his spare time, but he cannot resist the challenge. He adds that it pays in the long term because the machine supplier depends on his knowledge and expertise. "This gives us an advantage when buying new machines,” he says. (Extract from field notes 2007).

Bruce's story, though exemplary and non-representative, gives us a glimpse of how organization members through extensive collaboration at many levels are constantly changing routines, thereby incrementally reshaping the work roles and teams of which they are part. Research on cross functional teams shows in the same way that collaboration across traditional organizational boundaries leads to improvements in performance and innovations (e.g. Bunderson and Sutcliffe 2002; Gebert et al. 2006). Bruce’s story also illustrates how difficult it is for managers to intervene and design new routines as they are outside the stream of co-creation that changes the organization in small incremental steps.

The third recurrent observation is that firms with Danish managers had developed aspirations for and ways of gradually distributing as much authority as possible throughout the organization by delegating responsibility and agency to teams. In all cases, teams were typically hosting lateral accountability as well as intelligence, creating the foundation for a governance system based on mutual involvement. Research on self-managing and empowered work teams indicates that empowerment tends to create more productive and proactive teams (Kirkman and Rosen 1999; Stewart 2006) so this process seems very reasonable. Yet the gradual decentralization of agency was brought to a halt when American managers took over top positions in the case-firms and instead implemented standardized organizational templates. Maybe this reflects that the propensity to diffuse HPWO and the degree of empowerment of employees differs radically among countries and seems to have become especially hesitant in the U.S., where famous projects such as Saturn have not led to wide diffusion of otherwise successful modes of organization. Delegation of agency seems to have taken different roads in different countries (Minssen 2006; Werginn 2003; Woywode 2002). In particular, on the dimension of employee empowerment and decentralization of agency, Denmark, the Nordic countries and the Netherlands constitute a cluster where such "learning organization" has diffused widely. In Denmark $60 \%$ say they work in "learning organizations" (Lorenz and Valeyre, 2003), 85\% say that they are often or sometimes using their own ideas at work and working within a highly participatory organizational frame (Andersen, 2003) and 59\% say that they work with people from other firms on a daily basis and that customers rather than bosses set the pace and tasks of jobs (Undervisningsministeriet 2005; Eurofound 2007). Thus it seems that our case-studies are more representative for countries in which the transitions of work and the sophistication of team communities take on a process of cumulative causation, which however can be put on hold for a while by "alien” managerial interventions. 
These three recurrent observations compared to bipolar team models illustrate clearly that contemporary work teams come in many varieties and are not always an outcome of managerial action but instead of internal and external relational dynamics that continuously change modes and combinations of collaborative and laterally accountable team practices. Managerial intervention is only one among many ways of triggering these change processes. Therefore, new sensitizing, comparative, relational and dynamic conceptual frameworks are called for in order to understand the workings and co-creative dynamics of teamwork in contemporary firms. Our empirical observations suggest that a central step is to understand the comparative differences in the emergence of communities of teams, the agency they distribute, their internal and external relations and the way they create and change governance. Possible themes and questions relating to such an approach are discussed in the rest of the paper.

\section{What Happens to the Idioms of Teams When Teams are Taken Seriously as Economic Co-Creative Actors?}

Insisting on studying teams as communities within a larger community of teams implies a radical shift and questions many positions within the tradition of team studies.

One of the core concepts in the debate has circled around "autonomy" of the single team. Our findings contradict the normal concept of autonomy, because the more individual team members change roles within teams and the more they participate in organizational activities outside their operational teams and become enmeshed in inter-team activities, the more they can contribute to the reflexive practice of the teams with new stimuli to the internal rivalry over how to find ways of improving performance. The more widespread the stimulus is to change role, the more team members become able to take on the roles of others and reflect on these roles (cf. Mead 1934). The more they take part in cross-team discussions, the more new information and new points of reflection they can introduce in their primary team. Conversely, the more this happens, the more the members can carry back to the cross-team committees to help other teams reflect on their jobs. Thus for a community to evolve in the individual teams, it is very important that a community of deliberation is formed among the teams.

In teams where the life of the individual team is less enmeshed within the larger organizational framework and gatekeeper roles of communicating/coordinating with the larger organization are allocated to a limited number of team leaders, the workers' collective typically becomes divided into three diverse positions: enthusiasts, lukewarm defenders keeping some distance, and opponents who prefer to raise their voices outside the reflexive meetings, as we observed at an early stage in Spirit Ltd. Whereas the former group tries to create a formal system that sustains the evolution of a community of reflexive practitioners within and among the formal teams, the latter group tries to create an informal community (very similar to the workers' collective of Fordist factories) in opposition to the formal system. Among them, they fight to make a coalition with the lukewarm group. In such a system it is fairly difficult to develop a reflective community and traditional managerial roles are sustained. 
For a community of deliberation to take over the continuous self-reflection of a managerial team, formalized interdependencies and communication among teams is necessary (see also Minssen 2006) and this breaks with the rule of socio-technical theorizing that teams must be granted relatively high autonomy over a discrete set of tasks. Second, it breaks with the rule that within the teams, individual members should be granted fairly high autonomy over both planning and execution, as a community of deliberation is dependent on involving many with several roles so that practices and routines can mutually be called into question.

Thus the well-functioning team community breaks with another important rule on role conflict (Kahn et al., 1964). In this view role conflicts are sources of conflict and ambiguity and therefore lead to stress, which should be avoided. This is also why Burns and Stalker (1961) view the "organic organization" as utterly unstable, and see hierarchical role division and rule-bound behavior as necessary for stabilizing the organization. A community of deliberation around team communities seems to be an alternative route for "institutionalizing" a space in which individuals can play several roles and become triggered by continuous role conflicts.

Finally, our study breaks with the rule that measuring performance has negative effects on the community dimension of teams. Traditional literature taught us that performance measures would lead to a neo-Taylorist rather than an anti-Taylorist form of team dynamics (Pruijt, 2002). Instead, our cases indicate that elaborate measures are not only helping to improve on performance, but also sustain an informed communication among teams (see Kozlowski and Ilgen 2006 for a similar conclusion). Without a measuring system it is impossible to monitor the improvements in routines and roles and navigate a community of team communities. Performance measures tied to inducements in pay, however, may have harmful consequences for the team community.

A number of similar observations that conflict with the usual dichotomies of the literature could be made, but we think those mentioned suffice to indicate the need for a reinterpretation of the dynamics of team-based work organization. This we shall try to illustrate next.

\section{Evolutionary Dynamics of Communities of Team-Communities: A New Challenge to Comparative Business Studies}

The current "design" of the team-based organization of our cases is not an outcome of discrete planning but has evolved experimentally for at least one decade and in some instances for three, and none expects to have found a final form. In opposition to dual ideal types/states, our studies confirm recent findings (Kozlowski and Ilgens 2006) that the building of such organizational forms goes through a multifaceted process of learning and refinements, during which participants will have to change opinions and points of departure many times. In a way the most radical shift from previous Taylorist ideas is that there is no such thing as an "ideal state". While our studies indicate that communities of teams might evolve from less to more elaborate forms, this process unfolds as a sequence of highly frustrating events, which only in retrospect reveal their benefits and help create a constituting narrative of the firm as a community of teams. 
In the first phase of developing a team-based organization, there are a set of typical problems to overcome (Vallas 2003): structural inertia; resistance from middle-managers and opponentworkers; most changes happening through incremental innovations while the new forms of work-organization only function after bundles of reforms have accumulated (MacDuffie 1995); and the involvement of a shift from hierarchical to “discursive coordination” (Minssen 2006). In the U.S. it seems that difficulties in overcoming these problems were partly caused because managers started hierarchically implementing new lean principles by developing them in technical staff groups while neglecting the formation of autonomous teams (Vallas 2003; Blackburn and Benson 1993). Also in the Danish cases, the genesis of team-based work has been painful and has entailed conflicts, ambiguities and stress, and in the early phases opponents among the workers were able to create coalitions with middle managers and mobilize support from the group of only lukewarm defenders. Had such coalitions become dominant, it would have been impossible to acquire elaborate communities of teams.

Vallas (op cit) showed how conflictual interests slowed down the evolution of team-based organizations in three of four American plants. The fourth was successful because instead of subversive games, a continuity of negotiations among local union representatives and managers was institutionalized. Whereas in the U.S. negotiation procedures may only emerge exceptionally, in Danish companies the legacy of elected shop stewards, convenors, work council and board representatives makes it normal for conflicts to be handled by nexuses of negotiation. Such negotiations led to the formation of reform-partnership between top managers and convenors or other representatives from the floor (Kristensen 2003). These partnerships served to overcome the problems that hamper progress during the initial reform-process in many countries. With their relations to the larger complexes of Danish welfare institutions (vocational training institutions, labor market institutions, regional and local corporatist bodies) local union representatives constituted a particularly useful partner as they helped organize further training to empower teams, reform wage systems and help change public services towards the needs of the new working life (author b, forthcoming).

In our view, this partnership in particular made it possible for Denmark to follow an evolutionary process of forming HPWOs in a very different wayto that in the U.S. In Denmark the focus was on delegating increasing responsibility in step with employees being empowered by further training (during the 1990s Denmark became the EU's most further training intensive country), to the effect that operational teams became highly autonomous, whereas it was difficult to detect the management system that embedded autonomy (Lorenz and Valeyre 2003). This evolutionary step prepared for the next one during which operational teams became combined and recombined in ad hoc development projects. As this broke with the propensity for "silo-thinking" and for teams to be hostile fiefdoms, shop stewards and convenors (or new managerial role positions) took on the task of counteracting "silo-thinking" and fiefdom-strategizing by reorienting the negotiating order towards the lateral coordination of teams. This new negotiation regime in turn triggered the formation of a great number of temporary committees designed to solve problems of common interest among the teams. Obviously what happened was that the habit of negotiating diffused to every corner of the firms. In the late 1990s these were extremely experimental and innovative, as the rotation across teams of operatives led to much inspiration for learning and innovation. Yet it became obvious that firms were lacking an apparatus for making continuous and coordinated improvements on a systematic basis. This led to the new reform experiments that took place after 2000, a time when experiments with lean or 
TPM managerial concepts entered the scene. But instead of being installed in a neo-Taylorist way, new forms of self-managing cross-teams were set up to search for and mainstream improvements across teams.

It is easy to imagine how difficult it is for a firm to shift between an operative, an innovative and an improvement mode and these were exactly the type of problems that were encountered in the studied organizational forms. We would expect that attempts to deal with these problems would lead to the emergence of an even more advanced form of negotiating order. However, we have in no case seen that the firms have space for reconfiguring their governance systems. Our observations indicate that only by diffusing negotiations even more than is currently the case can the problems that Burns and Stalker (1961) predicted be overcome. This calls for managers and their "top adversaries" to focus on continuous negotiation over goal setting, monitoring/intervention, diagnosis and feedback, i.e. become the guardians of processes and procedures by which the underlying system evolves (Kozlowski and Ilgen 2006).

The previous section illustrates the evolutionary pattern of communities of teams within a Danish and organizational context. As we have tried to make clear, it runs through emergent states almost in reverse order compared to the U.S. This has great implications for the study of team-based organizations in different countries. Not only are they encountering very diverse barriers; they are also developing very different organizational ecologies and performances.

\section{A Quest for Future Comparative Team Research: Concluding Remarks}

For organization studies it is imperative to start studying these evolutionary patterns comparatively, as both leadership roles and organizational solutions will be directed towards highly divergent problems and because apparent similar phenomena may play very different roles in shaping the evolutionary direction of HPWOs. In what follows, some of the need for comparative studies will be identified.

First, we need more fine grained studies of existing orders of negotiation and their ability to diagnose, make feedback on, monitor and set goals for the organizational community of teams. Today the orders of negotiation are invisible, and there seems to be very little comparative assessment of different formation. Studies of how team-based organizations react to similar events in different countries are therefore needed.

There has been a tendency to see performance based pay systems as a route to neo-Taylorism. Perhaps one of the unexpected advantages of bonuses, profit sharing and co-ownership is that firms have been pushed to become much more financially transparent with such schemes. We think there is a need for comparative studies into how financial transparency is created and how it enters into the negotiations among teams, employees and managers. Further, how distributional and integrative negotiations (Sisson and Marginsson 2000) become intertwined to form new ways of carrying out interest aggregation in communities of teams. Different forms of financial transparency will also influence the ability for teams to take agency. In the studied cases, people at all levels were surprisingly well informed about how the teams perform comparatively and how the total outcome translates into the performance of the entire firm. The team members get information about individual and team performance enabling them to assess whether they 
should "try harder" individually and to consider whether their team has much to teach or a lot to learn from other teams. Thus in day-to-day dealings, such schemes furnish the members with questions and a willingness to search for answers when they meet with representatives of other teams. No doubt such information systems lead to operational rivalry, but they also trigger the possibility of reflexive collaboration. This balance is worth assessing comparatively.

We are also in need of comparative studies that can inform us about how managers cope with the role that the hierarchy above them imposes on them, and the shifting roles (and positions) they must take on in the ongoing negotiations that align much of the coordination taking place within the community of teams in the larger landscape of, for example, a multinational company.

By definition managers hold a veto, as they might decide to claim their right to fire "opponents" in negotiations or to close down an entire plant. After all, managers are seen from the outside (e.g. from shareholders, foreign headquarters, banks and other financial institutions, regulatory authorities, inspectors, certification bureaus, etc.) and to a different extent in different countries, to hold formal responsibility and hierarchical control, and they must look professional and be responsive to the general waves of mimetic isomorphism of their contexts (Meyer and Rowan 1991). So it is important to investigate how they deal with accommodating the two spheres differently in different countries. Further, in the firms investigated, managers typically intervene according to a set of templates for managerial and organizational reforms. Often they impose such templates on the organization - almost as self-assured about their hierarchical role as were the Penrosian managers of the past. In the cases studied these templates are captured by the negotiating community of teams as a way of reflecting on past practices. Paradoxically, then, managerial action leads not to the design of new routines and routine integrates, but rather evokes a process of self-doubt and reflection that triggers processes in which old ways of performing roles are questioned, evaluated and assessed to effect a clearer diagnostic sense of where the strengths and weaknesses of the current constitution of the community of teams lie. In this way, managerial intervention becomes part of a quite coherent evolutionary process, but it is likely to be expected that in other countries, team-based organizations become schizophrenic by adapting to shifting managerial templates and benchmarks.

Clearly, our cases showed a shortcoming as they had no procedure for negotiating the negotiating order. This means that they are communities without meta-government and the ability to initiate deliberate constitutional reform. This function rather remains with the multinationals that own them than with the managers that are expected to run them. As Mueller and Purcell (1992) and Kristensen and Zeitlin (2005) have shown, MNC HQs play out subsidiaries against each other through a continuous flow of benchmarks in association with investment and head-count bargaining. The rationale underlying this flow of shifting benchmarks is to force the subsidiaries to evaluate themselves and continuously question their own practices in the light of best practices. In many ways, this governance form stimulates the ongoing deliberations of the community of teams within a subsidiary by casting doubt on its current figuration. But the restless external flow of questions and reporting make it very difficult to imagine that it becomes possible for the community as such to reflect on its practices and through this to evolve a deliberate organization of negotiations. On the other hand, MNCs force their subsidiaries to make increasing use of subcontractors, to the effect that they force subsidiaries to collaborate across the formal boundaries of firms. Therefore, what the agency of teams 
becomes strongly depends on how they go about the deliberate relationships among firms at the local or regional level. We are in need of comparative studies into how firms become constituted differently in such complicated networks, and how this affects the co-creation and governance of communities of teams.

Our study demonstrates that the evolution and character of the communities of teams in the case companies under study has drawn on many distinctive institutional features of the Danish system: for instance, the culture of negotiation and collaboration among employers and unions, the network among firms in a small enterprise economy, further training institutions, welfare institutions etc. To gain knowledge of the general evolution of these organizational forms we therefore hope that future research will pave the way for a new wave of comparative studies identifying which institutional building blocks enter into their construction in different countries and how this has effect on the evolution and prospects of communities of teams. In our view, communities of teams seem to be the loci for combining global competition with human progress. If this is the case, comparative team studies are also a search for promising routes toward creating both organizational and human growth. 


\section{References}

Andersen, Jørgen Goul

2003 Over-Danmark og under-Danmark. Ulighed, velfcerdsstat og politisk medborgerskab. Aarhus: Aarhus Universitetsforlag.

Bacharach, Michael

2005 "Foreword: Teamwork” in Teamwork - Multi-disciplinary perspectives . Natalie Gold (eds). Palgrave Macmillan.

Bacon, Nicolas and Paul Blyton

2000 "High road and low road teamworking: Perceptions of management rationales and organizational and human resource outcomes”. Human Relations, 53(11): 1425-1458.

Barker, James R.

1993 “Tightening the iron cage: Concertive control in self-managing teams”. Admistrative Sceince Quarterly, 38(3): 408-437.

Barnard, Chester

1968 [1938] The functions of the executive. Cambridge, Mass.: Harvard University Press.

Bechky, Beth A.

2003 "Sharing Meaning across Occupational Communities: The Transformation of Understanding on Production Floor”. Organization Science vol. 14, no. 3, pp. 312-330.

Benders, Jos

2006 "Team working: A tale of partial participation" in Participation and democracy at work. Harley, Hyman and Thompson (eds). Palgrave Macmillan, London/Basingstoke.

Benders, Jos and Mark van Bijsterveld

2000 "Leaning on lean: the reception of a management fashion in Germany". New Technology, Work and Employment, 15(1), 50-64.

Benders, Jos and Geert Van Hootegem 
1999 “Team and their context: Moving the team discussion beyond existing dichotomies”. Journal of Management Studies, 36:5: 609-628.

Benders, Jos, Fred Huijgen and Ulrich Pekruhl

2002 "What do we know about the incidence of group work (if anything)?” Personnel Review, Vol. 31 No. 3: 371-385.

Blackburn, R. and R. Benson

1993 “Total Quality and human resource management: lessons learned from Baldridge Award.winning companies”. Academy of Management Executive, 7/3.

Broek, Diane van den, George Callaghan and Paul Thompson

2004 "Teams without teamwork? Explaining the call centre paradox". Economic and Industrial Democracy. (SAGE) Vol. 25(2): 197-218.

Brown, John Seely and Duguid, Paul 2001 "Knowledge and Organization: A Social-Practice Perspective”. Organization Science, vol. 12, no. 2, pp. 198-213.

Bundersen J. S. and Kathleen M. Sutcliffe

2002 "Comparing alternative conceptualizations of functional diversity in management teams: Process and performance effects”. Academy of Management Journal, 45(5): 875-893.

Burns, Tom, and George M Stalker

1961 The management of innovation. London: Tavistock.

Carroll, John S, Sachi Hatakenaka and Jenny W. Rudolph

2006 "Naturalistic decision making and organizational learning in nucleat power plants: Negotiating meaning between managers and problem investigation teams”. Organization Studies, 27(7): 1037-1057.

Casey, Catherine

1995 Work, self and society -after industrialism. Routledge, London. 
Chesbrough, Henry

2003 Open innovation. The new imperative for creating and profiting from technology. Cambridge, Mass: Harvard Business School Press.

Dalton, Melville

1959 Men Who Manage. New York: John Wiley and Sons

Delbridge, Rick, James Lowe and Nick Oliver

2000 “Shopfloor responsibilities under lean teamworking”. Human Relations, 53(11): 1459-1479.

Den Hertog F and T Tolner.

1996 “Groups and teams”. International Encyclopaedia of Business and Management. Thomson Business Press.

Elias, Norbert

1978 What is sociology? Hutchinson \& Co (Publishers) Ltd 1978.

Elias, Norbert

1974 "Foreword - Towards a Theory of Communities" in Bell, Colin and Newby, Howard The Sociology of Community. London: Frank Cass and Co. Ltd.

Emirbayer, Mustafa

1997 "Manifesto for a Relational Sociology”. The American Journal of Sociology, vol. 103, no. 2, pp. 281-317.

Eurofound (European Foundation for the Improvement of Living and Working Conditions)

2007 Fourth European Working Condition Survey Dublin: www.eurofound.europa.eu.

Fetterman, David M.

1989 Ethnography: Step by Step. SAGE.

Flyvbjerg, Bent

2001 Making Social Science Matter. Cambridge: Cambridge University Press.

Garibaldo, F and E. Rebecchi. 
2004 "Some reflections on the epistemological fundaments of an Italian action-research experience”. AI \&Society, 18: 44-67.

Gebert, Diether, Sabine Boerner and Eric Kearney.

2006 "Cross-Functionality and innovation in new product development teams: A dilemmatic structure and its consequences for the management of diversity”. European Journal of Work and Organizational Psychology, 15(4): 431-458.

Guzzo, Richard A and Marcus W. Dickson

1996 "Teams in organizations: Research on performance and effectiveness". Annual Review Psychology, 47: 307-38.

Heckscher, Charles and Adler, Paul S (eds)

2007 The Firm as a Collaborative Community. Reconstructing Trust in the Knowledge Economy. Oxford: Oxford University Press.

Herrigel, Gary

2007 "Roles and rules: Ambiguity, experimentation and new forms of stakeholderism in Germany". Mimeographed Manuscript. University of Chicago. January 2007.

Hochschild , Arlie Russell

1997 The time bind -when work becomes home and home becomes work. 1st American ed Metropolitan Books, New York.

Kahn, R., D. Wolfe. R. Quinn, J. D. Snoek and R. Rosenthal

1964 Organizational stress: Studies in role conflict and role ambiguity. New York: John Wiley and Sons.

Kanter, Rosabeth M.

1979 “Power failure in management circuits”. Havard Business Review 57: 65-75.

Keller, Robert T.

2001 "Cross-functional project groups in research and new product development: Diversity, communication, job stress and outcomes”. Academy of Management Journal, 44(9): 547-555.

Kenney, Martin and Richard Florida

1993 Beyond Mass Production: The Japanese System and Its Transfer to the U.S.. New York: Oxford University Press. 
Kirkman, Bradley L and Benson Rosen.

1999 “Beyond self-management: Antecedents and consequences of team empowerment”. Academy of Management Journal 50(1): 58-74.

Knights, David and Darren McCabe

2000 "Bewitched, bothered and bewildered: The meaning and experience of teamworking for employees in automobile company”. Human Relations, 53(11): 1481-1517.

Koch, Christian.

2004 "The tyranny of projects: teamworking, knowledge production and management in consulting engineering”. Economic and Industrial Democracy, 25(2): 277-300.

Koch C. and H. Buhl.

2001 “ERP-supported teamworking in Danish manufacturing?”. New Technology Work and Employment, 16(3): 164-77.

Kozlowski, Steve W. J. and Daniel R. Ilgen.

2006 "Enhancing the effectiveness of work groups and teams". Psychological Science in the Public Interest. 7(3): 77-124.

Kristensen, Peer Hull and Jonathan Zeitlin

2005 Local players in global games - The strategic constitution of a multinational corporation. Oxford, New York.

Kristensen, Peer Hull

2003 Et Græenseløst Arbejde. En fantastisk fortælling om danske tillidsvalgtes arbejde, indflydelse og fremtid i multinationale datterselskaber. Copenhagen: Nyt fra Samfundsvidenskaberne.

Kristensen, Peer Hull

1986 Teknologiske Projekter og Organisatoriske Processer. Strategier og strukturer under forandring i danske virksomheders drift mod fleksibel specialisering. Roskilde: Forlaget for Samfundsøkonomi og Planlægning.

Kuipers, B. S. and M. C. de Witte.

2005 "The control structure of team-based organizations: A diagnostic model for empowerment". Economic and Industrial Democracy, 26(4):621-643. 
Kunda, Gideon

2006 Engineering Culture - Control and Commitment in a High-Tech Corporation. Philadelphia: Temple University Press.

Lee, David, and Howard Newby

1995 The problem of Sociology. Routledge, London.

Lorenz, Edward and Antoine Valeyre

2003 Organizational Change in Europe: National Models or the Diffusion of a New “One Best Way”?

Prepared for the $15^{\text {th }}$ Annual Meeting on Socio-Economics, LEST, Aix en Provence, June 26-28.

Lotz, Maja

2009 The Business of Co-creation - and the Co-creation of Business. PhD Series 15. 2009, Copenhagen Business School.

MacDuffie, J. P.

1995 "Human resource bundles and manufacturing performance: organizational logic and flexible production systems in the world auto industry”. Industrial and Labor Relations Review, 48(2): 197-221.

Mead, Georg Herbert (

1934/1967 Mind, Self and Society. Chicago: The University of Chicago Press.

Meyer, John W. and Brian Rowan

1991 Institutionalized organizations: Formal structure as myth and ceremony, in The new institutionalism in organizational analysis. Paul J. DiMaggio and Walter W. Powell (eds). Chicago: The University of Chicago Press.

Minssen, Heiner

2006 “Challenges of Teamwork in Production: Demands of Communication”. Organization Studies 27(1)

103-124 
Morgan, Glenn; Richard Whitley and Eli Moen

2005 Changing capitalisms? Internationalization, institutional change and systems of economic organization. Oxford: Oxford University Press.

Mueller, Frank, Stephen Proctor and David Buchanan.

2000 “Teamworking in its context(s): Antecedents, nature and dimensions”. Human Relations, 53: 13871424.

Mueller, Frank

1994 "Teams between hierarchy and commitment: Change strategies and the 'internal environment'”. Journal of Management Studies 31:3: 383-403.

Mueller, Frank and John Purcell

1992 "The Europeanization of manufacturing and the decentralization of bargaining: multinational management strategies in the European automobile industry”. International Journal of Human resource Management, 3, 15-31.

Nelson, Richard R. and Sidney Winter

1982 An evolutionary theory of economic change. Cambridge, Mass.: Harvard University Press.

Penrose, Edith T.

1980 [1959] The Theory of the Growth of the Firm. Oxford: Blackwell.

Procter, Stephen and Graeme Currie

2004 “Target-based teamworking: Groups, work and interdependence in UK Civil Service”. Human relations, 57(12): 1547-1572.

Pruijt, Hans

2002 "Neo-Tayloristic and anti-Tayloristic models of team-working”. Paper presented at the IAS World Congress of Sociology, Research Committee 26, July 7-12 2002.

Sabel, Charles F.

2006 ‘A Real-Time Revolution in Routines’. In Heckscher and Adler (eds): 106-156. 
Scarbrough, H. and N. Kinnie

2003 'Barriers to the development of teamworking in UK firms'. Industrial Relations Journal 34/: 135-149.

Senge, Peter

1990 The fifth discipline. New York: Doubleday

Sennett, Richard

1998 The corrosion of character

-the personal consequences of work in the new capitalism. Norton, New York

Sewell, Graham.

1998 "The discipline of teams: the control of team-based industrial work through electronic and peer surveillance”. Administrative Science Quarterly, 43(2): 397-428.

Sinclair, Amanda

1992 “The tyranny of team ideology”. Organization Studies, 13: 611-626.

Sisson, Keith and Paul Marginson

2000 “Coordinated bargaining: A process for our times? ESRC 'One Europe or Several'Programme. Working Paper 14/00, University of Sussex European Institute.

Spradley, James P.

1979 The Ethnographic Interview. Michigan: Wadsworth Group.

Stake, Robert E.

1998 'Case Studies’, in Denzin, Norman K. and Lincoln, Yvonna (Eds),

Stark, David

2009 Assets of Ambiguity - Accounts of Worth in Economic Life. Princeton University Press.

Steijn, Bram.

2001 "Work systems, quality of working life and attitudes of workers: An empirical study towards the effects of team and non-teamwork”. New technology, Work and Employment, 16(3): 191-203. 
Stewart, Greg L.

2006 "A meta-analytical review of relationships between team design feautures and team performance". Journal of Management, 32 (1): 29-55

Stewart, Greg L. and Murray R. Barrick.

2000 "Team structure and performance: Assessing the mediating role of intrateam process and the moderating role of task types”. The Academy of Management Journal, 43 (2): 135-148

Strang, David and Dong-II Jung.

2009 "Participatory improvement at a global bank: The diffusion of quality teams and the demise of sis sigma initiative”. Organization Studies, 30(01): 31-53.

Sundstrom, E, K. P. de Meuse and D Futrell

1990 ”Work team. Applications and effectiveness”. American Psychologist, 45:2, 120-33.

Tilly, Charles

2006 Why? What happens when people give reasons....and why. Princeton University Press.

Townsend, Keith.

2007 “Who has control in teams without teamworking?”. Economic and Industrial Democracy, 28(4): 622649.

Uhl-Bien, M. and G. B. Graen

1998 "Individual self-managment: Analysis of profesisionals' self-managing activities in functional and cross-functional work teams”. Academy of Management Journal, 41(3): 340-350.

Undervisningsministeriet

2005 Det nationale kompetenceregnskab. Hovedrapport. Copenhagen

Vallas, Steven P.

2003 "Why teamwork fails: Obstacles to workplace change in four manufacturing plants".

American Sociological Review, 68(2): 223-250. 
Van Hootegem, Gert, Jos Benders, Anne Delarue and Stephen Procter.

2005 “Teamworking: looking back and forward”. The International Journal of Human Ressource Management, 16(2): 167-173.

Van den Broek, George Callaghan and Paul Thompson.

2004 "Teams without teamwork? Explaining the call centre paradox". Economic and Indutrial Democracy, 25(2): 197-218.

Van Maanen, John

1988 Tales of the Field. Chicago: The University of Chicago Press.

Wergin, N.-E.

2003 'Teamwork in the automobile industry: An Anglo-German comparison’. European Political Economy Review 1(2): 152-190.

Whitley, Richard

1987 "Taking firms seriously as economic actors: Towards a sociology of firm behavior". Organization Studies, 8: 125-47

Whitley, Richard

1999 Divergent capitalisms. The social structuring and change of business systems. Oxford: Oxford University Press.

Whitley, Richard and Peer Hull Kristensen, editors

1996 The changing European firm. Limits to convergence. London: Routledge.

Whitley, Richard and Peer Hull Kristensen, editors

1997Governance at work. The social regulation of economic relations. Oxford: Oxford University Press

Womack, J.P., D. T. Jones D. and Roos

1990 The Machine That Changed the World. New York: Rawson Associates.

Woywode, $\mathrm{M}$.

2002 'Global Management concepts and local adaptations: Working groups in the French and German Car industry. Organization Studies 23/4: 497-524. 
Yin, Robert K.

2003 Case Study Research Design and Methods. London: Sage Publications. 